molodshykh shkolyariv na urokakh muzyky $v$ umovakh polikulturnoho prostoru [Upbringing of tolerance among younger students in music lessons in the conditions of multicultural space]. Candidate's thesis. 242 p. Luhansk. [in Ukrainian].

5. Maykovskaya, L. S. (2009). Fenomen etnokulturnoy tolerantnosti $\mathrm{v}$ muzykalnom obrazovanii [The phenomenon of ethnocultural tolerance in music education]. Doctor's thesis. Moscov. 48 p. [in Russian].

6. Masol, L. M. (2006). Zahalna mystetska osvita: teoriya i praktyka [General Art Education: Theory and Practice]. Kyiv, 432 p.[in Ukrainian].

7. Slovnyk ukrayinskoyi movy (1979). [Dictionary of the Ukrainian language]. in 11 volumes. Volume 10. Kyiv, 163 p. [in Ukrainian].
8. Stukalenko, Z. M. (2016). Formuvannya profesiynoyi tolerantnosti maybutnoho vchytelya muzychnoho mystetstva $\mathrm{v}$ protsesi fakhovoyi pidhotovky [Formation of professional tolerance of future teacher of music art in the process of professional training]. Candidate's thesis. Kirovohrad, 296 p. [in Ukrainian].

9. Fedorchenko, V. K. (2002). Humanizatsiya vyshchoyi osvity: imperatyvy ta problemy [Humanization of higher education: imperatives and problems]. Kyiv-Zaporizhzhya. Vol.25, pp.16-21. [in Ukrainian].

10. Cherkasov, V. F. (2012). Vplyv tolerantnosti na formuvannya estetychnoyi kultury molodi [Influence of tolerance on the formation of aesthetic youth culture]. Kirovohrad, Vol.106, pp.121-128. [in Ukrainian].

Стаття надійшла до редакції 24.10.2019

УДК 378:364.48

DOI:

Юлія Грач, кандидат педагогічних наук, доиент кафедри соиіальної роботи і сочіальної педагогіки Хмельницького національного університету

\title{
РОЛЬ СОЩАЛЬНО-ВИХОВНИХ МЕХАНІЗМІВ У ПРОЦЕСІ СОЩАЛІЗАЦЇ̈ СТУДЕНТСЬКОЇ МОЛОДІ В СУЧАСНИХ УМОВАХ ЗДОБУТТЯ ВИЩОЇ ОСВІТИ
}

У статті висвітлюються проблеми соиіалізаиії студентської молоді у проиесі здобуття вищої освіти. Наводиться порівняльний аналіз поняття соиіалізації у різних наукових концепиіях. Автор акиентує увагу на ролі та значенні сочіально-виховних механізмів у прочесі навчання в закладах вищої освіти. Подається до розгляду авторське визначення поняття "сочіально-виховні механізми соціалізації у процесі здобуття вищої освіти”. Автор пропонує до розгляду визначення поняття “сочіалізація студентської молоді".

Ключові слова: сочіалізачія; студентська молодь; соиіальна адаптачія; соиіально-виховний механізм. Jim. 5.

Juliya Hrach, Ph.D.(Pedagogy), Associate Professor of the Social Work and Social Pedagogy Department Khmelnytskiy National University

\section{THE PURPOSE OF SOCIO-EDUCATIONAL MECHANISMS IN THE PROCESS OF SOCIALIZING STUDENT YOUTH IN MODERN CONDITIONS TO OBTAIN HIGHER EDUCATION}

The article highlights the problems of socialization of student youth in the process of higher education. The author analyzes the essence, features and mechanisms of the socialization process. The article provides a comparative analysis of the socialization concept in different scientific conception. The author defines the concept of socialization in sociology, psychology, pedagogy and social pedagogy. In the article the author analyzes the understanding of the essence of socialization and possible mechanisms of successful implementation of this process. The author submits for consideration the definition of the content, purpose and tasks of the socialization process in different scientific concepts. The article defines the process of socialization as that having a multilevel and multidimensional character. The author explores the sociological theories of socialization that interpret the development of society as a continuous dialectical process, carried out in the unity of three aspects: externalization; objectification; and internationalization. The author focuses on the role and importance of social and educational mechanisms in the educational process in higher education institutions. In the article the author reveals the mechanism of socialization through internalization and from the standpoint of adaptive development concept. The author considers the definition of social adaptation as a platform on which to build new social experience and a link between the human social essence and social reality. The author defines the concept "social and educational mechanisms of socialization in the process of higher education". The author considers the institution of higher education as an open socio-cultural system. The author defines the connection of the higher education institution as a social institute with various socially significant institutions. In the article higher educational institutions are considered in cooperation with cultural and leisure 


\section{РОЛЬСОЦАЛЬНО-ВИХОВНИХ МЕХАНІЗМІВ У ПРОЦЕСІ СОЦАЛІЗАЦЇ СТУДЕНТСЬКОӤ МОЛОДІ В СУЧАСНИХ УМОВАХ ЗДОБУТТЯ ВИЩОЇ ОСВІТИ}

centers, clubs, practically oriented institutions and organizations for practice-oriented training. The author proposes the author's definition of the "socialization of student youth" concept.

Keywords: socialization; student youth; social and educational mechanism.

П остановка й обгрунтування актуальності проблеми. Сучасний світ швидко змінюється у соціальному, культурному, професійно спрямованому контексті, змінюються цінності, норми, пріоритети у житті кожного громадянина. Особливо гостро постає питання мінливості, динамічності сучасного суспільства для молоді. Нестабільність політичної ситуації, соціально-економічні ризики, криза духовних цінностей суспільства та невпевненість у майбутньому ставлять завищені вимоги для формування особистості, для визначення свого місця та соціальної ролі у суспільстві. Такі реалії українського суспільства актуалізують необхідність пошуку нових механізмів впливу на успішне становлення особистості задля забезпечення стабільного, комфортного та успішного життя. Криза вищої освіти постає ключовим спонукальним механізмом занепаду суспільства та втрати можливостей для інтелектуального розвитку молоді. У контексті професійної спрямованості та прагненні до особистого та професійного розвитку зазначені проблеми виступають наріжним каменем розвитку суспільства та держави в цілому.

Аналіз основних досліджень і публікацій. Проблема соціалізації молоді знайшла досить широке відображення у дослідженнях як вітчизняних (С. Диба, Л. Завацька, І. Звєрєва, О. Карпенко, О. Кузьменко, Н. Лавриченко, Г. Лактіонова, С. Савченко, С. Харченко, Н. Чернуха, Ю. Возна та ін.), так і зарубіжних (В. Бочарова, I. Кон, Г. Ландберг, А. Маслоу, Р. Мертон, А. Мудрик, Т. Парсонс, Б. Паригін, К. Роджерс, М. Шакурова та ін.) учених.

Теоретичному і практичному аналізу питань співпраці соціальних інститутів у вирішенні проблем виховання і соціалізації молодої людини присвячені праці вітчизняних, зокрема (О. Безпалько, Р. Вайноли, О. Вакуленко, А. Капської, М. Лукашевича, Л. Міщик та ін.), а також зарубіжних вчених (М. Гурьянової, Ф. Зайбель, Б. Мандея, А. Муравйов-Апостола, Е. Торай, К. Франер, Б. Хамфріса, Ф. Шервіша та ін.).

Метою статті $\epsilon$ теоретичне обгрунтування проблеми соціалізації студентської молоді у контексті ролі соціально-виховних механізмів в сучасних умовах здобуття вищої освіти.

Виклад основного матеріалу. На сучасному етапі розвитку українського суспільства особливої актуальності набуває проблема соціалізації як важливої мети і складової соціального виховання молоді.
Одним 3 найбільш важливих завдань процесу соціального виховання сучасної молодої людини $\epsilon$ завдання сприяти його входженню в практику суспільного буття, суспільної діяльності, норми і критерії яких становлять незалежну від нього об'єктивну реальність.

Необхідною передумовою вивчення особливостей соціалізації студентської молоді у процесі здобуття вищої освіти $є$ з'ясування суті, особливостей i механізмів досліджуваного процесу.

У "Великому тлумачному словнику сучасної української мови", в якому викладено найбільш усталені наукові знання, “соціалізація” трактується як процес засвоєння людиною певної системи знань, норм і цінностей, які дозволяють їй функціонувати як повноправному члену суспільства $[2,1360]$.

У контексті нашого дослідження 3 метою 3'ясування суті поняття “соціалізація” важливим $€$ підхід до розуміння сутності відмінностей його трактування української дослідниці Ю.В. Возної $[3,12]$. Здійснений порівняльний аналіз свідчить, що не тільки в різних наукових галузях спостерігаються певні відмінності його трактування, але навіть в одній галузі немає єдиного підходу щодо розуміння його суті, способів і механізмів реалізації.

Як свідчить аналіз наукової літератури, у соціології поняття “соціалізації” трактують як:

- у контексті “адаптації”, яка, на думку Г. Ландберга, полягає у взаємодії, завдяки якій індивід засвоює нормативні вимоги суспільства, уміння, вірування, звичаї з метою ефективної участі у соціальному житті;

- як процес входження особистості в соціальну і соціокультурну сфери та пристосування іiі до соціальних, культурних та психологічних факторів, тобто як компонент процесу соціальної інтеграції (Т. Парсонс); іiі “олюднення”, що передбачає як біологічні передумови, так і безпосереднє входження індивіда в соціальне середовище, що включає в себе соціальне пізнання, соціальне спілкування, оволодіння навичками практичної діяльності, активну перебудову навколишнього середовища (як природного, так і соціального); зміну і якісне перетворення самої людини, iї всебічний і гармонічний розвиток (Б. Паригін);

- як процес становлення особистості як соціальної істоти, під час якого формуються різноманітні їі зв'язки з суспільством, засвоюються орієнтації, цінності, норми, відбувається розвиток особистісних властивостей, набувається 
РОЛЬ СОЦІАЛЬНО-ВИХОВНИХ МЕХАНІЗМІВ У ПРОЦЕСІ СОЩАЛІЗАЦЇ СТУДЕНТСЬКОӤ МОЛОДІ В СУЧАСНИХ УМОВАХ ЗДОБУТТЯ ВИЩОЇ ОСВІТИ

соціальний досвід, що нагромаджений людством (М. Лукашевич);

- сукупність всіх соціальних процесів, спрямованих на засвоєння та відтворення індивідом певної системи знань, норм і цінностей, що дозволяють йому функціонувати у якості повноправного члена суспільства (І. Кон);

- як розвиток і самореалізація людини протягом усього життя в процесі засвоєння й відтворення культури суспільства (Г. Осипов).

Як свідчить аналіз наукової літератури, у психологічних дослідженнях “соціалізація” розкривається у контексті осмислення процесів:

- самоактуалізації “Я-концепції”, що полягає у саморозвитку і самореалізації особистості у процесі засвоєння соціального досвіду і набуття (оволодіння) нею особистого, індивідуального досвіду (Ш. Амонашвілі, А. Маслоу, К. Роджерс);

- становлення особистості, включаючи самосвідомість; засвоєння індивідом соціального досвіду, цінностей, норм, установок, зразків поведінки, певних ролей і функцій, притаманних суспільству, соціальній спільності, групі (Я. Коломинський, І. Кон, Г. Костюк, Б. Паригін);

- входження особистості в групу на основі таких механізмів соціалізації, як наслідування, навіювання, конформізм, свідоме дотримання зразків, вплив масових засобів комунікації й культури (Г. Андрєєва, Є. Кузьміна, А. Петровський, А. Реан) $[3,16]$.

У педагогічних дослідженнях "соціалізація" розглядається як система виховання, розвитку, самовизначення та становлення особистості у соціумі. Так в "Українському педагогічному словнику” за редакцією С. Гончаренка (Київ, 1997) поняття “соціалізація” трактується як процес залучення індивіда до системи суспільних відносин, формування його соціального досвіду, становлення й розвитку як цілісної особистості.

Для нашого дослідження особливого значення набуває осмислення суті соичіалізації і можливих механізмів успішної реалізації изього процесу. У цьому аспекті значні напрацювання має соціальна педагогіка, як галузь педагогіки, яка досліджує соціальне виховання в контексті соціалізації. Як свідчить аналіз наукових напрацювань, соціальна педагогіка вносить своєрідне концептуальне осмислення феномену соціалізації у контексті:

- осмислення процесу соціалізації як пошуку нового підходу щодо трактування мети і змісту виховання;

- переосмислення мети соціалізації;

- пошуку технологій оволодіння особистістю соціальним досвідом.
У соціальній педагогіці соціалізація трактується як:

- двосторонній, взаємозумовлений процес взаємодії людини і соціального середовища, що передбачає їі включення до системи суспільних відносин (А. Капська);

- педагогічно керований процес, у ході якого відбувається становлення соціальної сутності молодої людини, опанування нею соціальної реальності (Н. Лавриченко);

- процес становлення особистості, засвоєння соціально-культурного досвіду, соціальних норм і культурних цінностей суспільства (С. Чернета);

- включення її в соціальну практику, набуття соціальних якостей, засвоєння соціального досвіду і реалізації власної сутності шляхом виконання певної ролі в процесі життєдіяльності (Ф. Мустаєва);

- розвитку і самореалізації людини впродовж усього життя в процесі засвоєння й відтворення культури суспільства (О. Мудрик).

За своїм змістом соціалізація є двобічним процесом, який передбачає, з одного боку, засвоєння індивідом соціального досвіду шляхом входження в соціальне середовище, систему соціальних зв'язків, 3 іншого - активне відтворення індивідом системи соціальних зв'язків за рахунок його діяльності, входження в соціальне середовище.

Мета соціалізації дослідниками трактується як:

- включення особистості до системи суспільних відносин шляхом засвоєння соціального досвіду, становленні її як соціальної істоти (А. Мудрик);

- цілеспрямований вплив на формування суспільних орієнтацій, установок, самовизначень і диспозицій особистості (цей аспект соціалізації відображається поняттям соціальної адаптації та становленням соціальної активності особистості, єдність яких виражена в поняттях соціальної інтеграції та життєвої самореалізації особистості (Н. Лавриченко);

- виховання активної особистості в процесі їі взаємодії із соціальним середовищем, усвідомлення нею необхідності повного розвитку своїх здібностей та потенцій (О. Волохов) $[3,16]$.

Для нас важливим $є$ висновок Н. Лавриченко про те, що процеси соціалізації в кожному суспільстві мають багаторівневий і багатоаспектний характер. Чим більш складним і відкритим стає суспільство, тим, відповідно, складнішими стають зміст і форми реалізації процесів соціалізації, а, отже, і завдання інституцій освіти, виховання та соціалізації молоді. 


\section{РОЛЬ СОЦІАЛЬНО-ВИХОВНИХ МЕХАНІЗМІВ У ПРОЦЕСІСОЦІАЛЗАЦЇ СТУДЕНТСЬКОЇ МОЛОДІ В СУЧАСНИХ УМОВАХ ЗДОБУТТЯ ВИЩОЇОСВІТИ}

У контексті здійснюваного дослідження
важливими є соціологічні теорії соціалізації
(П. Бергер, Т. Лукман ), які трактують розвиток
суспільства як безперервний діалектичний процес,
що здійснюється в єдності трьох аспектів:

1) екстерналізації - реалізації людської сутності в дії, в бутті, проекції суб'єктивних індивідуальних значень на об'єктивно сущий світ та його перетворення;

2) об 'єктивації-усвідомлення навколишньої дійсності як об'єктивно даної;

3) інтерналізації - безпосереднього сприйняття та усвідомлення об'єктивних фактів дійсності як суб' єктивно значимих $[1,102]$. Кожен член суспільства екстеріоризує себе у соціальному світі та інтерналізує його як об'єктивну реальність. Інтерналізація у загальному значенні - це підгрунтя розуміння індивідом, по-перше, людей, які його оточують, по-друге, світу як значимої і соціальної реальності.

Для нашого дослідження особливе значення мають надбання дослідників щодо осмислення механізмів соціалізаціі. У процесі аналізу ми встановили, що під механізмом соціалізації, зазвичай, розуміють способи й засоби, що сприяють засвоєнню індивідом соціального досвіду. У соціальній педагогіці загальноприйнятим $\epsilon$ розуміння механізмів соціалізації як системи зв'язків і відносин, що мають вагомий вплив на формування особистості (iіi потреб, мотивів, ціннісних орієнтацій тощо).

Л. Виготський, А. Лурія розкривають механізм соціалізачіі через інтеріоризацію, що грунтується на привласненні суспільноісторичного досвіду. Залежно від уявлень про інтеріоризацію виокремлюють різні грані цього процесу - індивідуалізацію, інтимізацію й вироблення внутрішнього плану свідомості $[4,112]$.

Український дослідник М. Лукашевич $[5,53]$ розкриває механізм соціалізації особистості 3 позицій адаптивно-розвивальної концепиії, суть якої полягає у трактуванні соціалізації як взаємодії людини, що триває впродовж усього ii життя, 3 навколишнім середовищем шляхом адаптацій у різних сферах життєдіяльності. Адаптація (як особливий вид діяльності людини), передбачає постійне засвоєнням суб'єктивно нової для індивіда соціальної ситуації, що сприяє збагаченню iii соціального досвіду і тим самим підвищує рівень його соціалізації $[5,78]$.

Соціальна адаптація, на думку дослідника, слугує платформою, на якій вибудовується новий соціальний досвід; вона є з'єднувальною ланкою між соціальною сутністю людини та суспільною дійсністю, що сприяє розвитку і збагаченню соціального середовища й соціальної природи людини. Якщо розглядати здатність до соціалізації як вроджену властивість людини, що забезпечує iii здатність до розвитку в різних напрямах, то процес соціальної адаптації варто розглядати не лише як активно-пристосувальний, а як активнорозвивальний. Ми погоджуємося 3 думкою М. Лукашевича, що особистість настільки соціально успішна, наскільки вона адаптивна; адже за кожною соціальною роллю стоять певні нормативи, а простір соціальних ролей і соціальних відносин практично є тим середовищем, у якому особистість адаптується.

Варто зазначити, що соціально-виховні механізми соціалізації у процесі здобуття вищої освіти ми розуміємо як “умови, чинники та критерії, які зумовлюють соціальний розвиток та особистісно-професійне становлення сучасного студента". При цьому 3ВО як первинний соціальний інститут для студента ми розглядаємо як відкриту соціально-педагогічну систему, як відкритий соціокультурний виховний механізм, який слугує тією платформою, на якій і вибудовуються якісно нові, соціально та науковопрофесійні компетенції майбутніх фахівців. Характеристика ЗВО як відкритої соціокультурної системи визначає зв'язок цього соціального інституту з різними соціально значущими інституціями, що безпосередньо чи опосередковано визначають соціально активне та якісно наповнене студентське життя. Сюди ми відносимо культурно-дозвіллєві центри, клуби, практично орієнтовані установи та організації для проходження практики та практико-орієнтованого навчання, зустрічі та знайомства студентів 3 успішними людьми, участь у науково-практичних конференціях, соціальна мобільність студентів, волонтерська діяльність тощо.

У контексті вище викладених положень про сутність соціалізації взагалі та соціалізації студентської молоді зокрема, вважаємо за доречне подати авторське визначення поняття “соціалізація студентської молоді” як “складний, різновекторний, активно-розвиваючий процес соціокультурної адаптації та особистіснопрофесійного становлення під впливом соціальновиховних механізмів сучасного суспільства".

Висновки. В умовах зниження престижу вищої освіти для сучасного українського студента проблема соціальної адаптації, мобільності, а відтак, умови успішної професійної реалізації стає необхідною складовою якісно нового, конструктивного та соціально активного процесу становлення як фахівця обраної спеціальності. Враховуючи динаміку змін у сучасному просторі 


\section{РОЛЬ СОЦІАЛЬНО-ВИХОВНИХ МЕХАНІЗМІВ У ПРОЦЕСІ СОЦІАЛЗАЦІЇ СТУДЕНТСЬКОЇ МОЛОДІ В СУЧАСНИХ УМОВАХ ЗДОБУТТЯ ВИЩОЇ ОСВІТИ}

здобуття вищої освіти, соціалізацію студентської молоді варто розглядати у контексті соціальновиховних механізмів впливу на зазначений процес. При цьому заклад вищої освіти слугує соціально значимою платформою, на якій вибудовуються якісно нові моделі особистісно-професійного розвитку, формуються професійні компетенції, наукове мислення, що $є$ необхідною умовою формування компетентного, конкуренто спроможного фахівця обраної спеціальності.

Рекомендації. В сучасних умовах здобуття вищої освіти процес соціалізації студентської молоді є у своїй більшості об'єктивним, проте він носить нескоординований, а інколи - суперечливий характер і тому потребує координації, інтеграції і корекції. У цьому контексті варто актуалізувати роль та соціальне значення соціально-виховних механізмів у процесі соціалізації сучасного студентства. Визначальним соціально-виховним механізмом при цьому вважаємо заклад вищої освіти як відкриту соціокультурну систему, професійно орієнтоване та особистісно розвиваюче значення якого визначаємо як ключове у процесі соціалізації студентської молоді. Рекомендуємо активізувати якісно нові соціально значимі механізми впливу на процес соціалізації студентства, впровадити інноваційні моделі якісних соціально-професійних змін у процесі професійного становлення майбутніх фахівців.

Перспективи подальших досліджень. Напрями подальших досліджень окресленої проблеми полягають у розробці соціальноорієнтованих інноваційних форм та методів організації навчально-виховного процесу, соціально-орієнтованої організації дозвілля та мотиваційному заохоченні студентів до науковопрактичної діяльності, створенні навчальнодослідних умов формування професійно важливих компетенцій у процесі поєднання теоретичної підготовки та соціокультурної діяльності майбутніх фахівців.

\section{ЛІТЕРАТУРА}

1. Бергер П., Лукман Т. Социальное конструирование реальності. Моква, 1995. $320 \mathrm{c}$.

2. Великий тлумачний словник сучасної української мови (з дод. і допов.) / Уклад. і голов. ред. В.Т. Бусел. Київ, 2005. 1728 с.

3. Возна Ю. В. Соціалізація учнівської молоді в процесі функціонування соціально-педагогічного комплексу. дис... кандидата пед. наук: 13.00.05. Київ, 2012. 276 арк.

4. Неперервна професійна освіта: філософія, педагогічні парадигми, прогноз: Монографія / В. П. Андрущенко, І. А. Зязюн, В. Г. Кремень, С. Д. Максименко, Н. Г. Ничкало, С. О. Сисоєва, Я. В. Цехмістер, О. В. Чалий / За ред. В. Г. Кременя. Київ, 2003.853 с.

5. Соціалізація. Виховні механізми і технології: навч.-метод. Посібник М. П. Лукашевич Київ, 1998. 229 c.

\section{REFERENCES}

1. Berher, P. \& Lukman, T. (1995). Sotsyalnoe konstruyrovanye realnosti [Social construction of reality]. Moscow, 320 p. [in Russian].

2. Busel, V.T. (2005). Velykyi tlumachnyi slovnyk suchasnoi ukrainskoi movy (z dod. $i$ dopov.) [A great explanatory dictionary of modern Ukrainian]. Kyiv, 1728 p. [in Ukrainian].

3. Vozna, Yu.V. (2012). Sotsializatsiia uchnivskoi molodi $\mathrm{v}$ protsesi funktsionuvannia sotsialnopedahohichnoho kompleksu [Socialization of student youth in the process of functioning of social and pedagogical complex]. Candidate's thesis. Kyiv. [in Ukrainian].

4. Andrushchenko, V. P., Ziaziun, I.A., Kremen, V.H., Maksymenko, S.D., Nychkalo, N.H., Sysoieva, S.O., Tsekhmister, Ya.V. \& Chalyi, O.V. (2003). Neperervna profesiina osvita: filosofiia, pedahohichni paradyhmy, prohnoz: Monohrafiia [Continuing Professional Education: Philosophy, Pedagogical Paradigms, Forecast: Monograph]. Kyiv, 853 p. [in Ukrainian].

5. Lukashevych, M.P. (1998). Sotsializatsiia. Vykhovni mekhanizmy i tekhnolohii [Socialization. Educational mechanisms and technologies]. Kyiv, 229 p. [in Ukrainian].

Стаття надійшла до редакції 18.10.2019

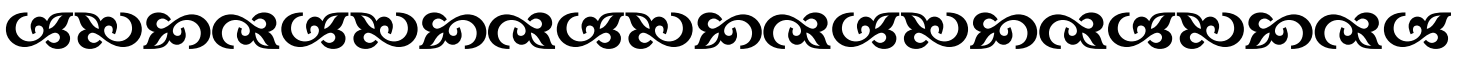

“Не роби ніколи того, чого не знаєи. Але навчися всього, що слід знати". Tiøбагор Самоський давньогреиький біхособ і математик

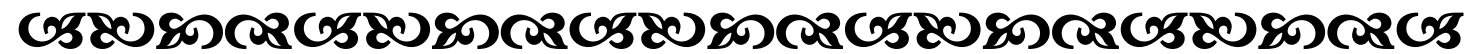

